\title{
Political Lords and Political Ideology in Southeastern Chiefdoms: Comments and Observations
}

\author{
Mary W. Helms \\ University of North Carolina at Greensboro
}

\begin{abstract}
This collection of papers highlights contexts in which ideology seems to have played a leading role in the political life of Southeastern societies. In this essay it is assumed that these polities operated within a general cosmological perspective based on belief in the consubstantiality of life. It is also assumed that association with qualities of distant time and space conveyed political legitimation to high elites. Building on these assumptions the significance of chiefly contacts with both horizontal (geographical) and vertical (celestial) external domains is examined and discussed.
\end{abstract}

Many of the papers originally presented in the session devoted to Lords of the Southeast at the Mobile meeting of the Southeastern Archaeological Conference and those collected in this volume argue directly or indirectly that political ideology as much as political economy energized critical components of Southeastern chiefdoms during the prehistoric era. Political ideology broadly defined was largely responsible for stimulating and maintaining the centralized or "chiefly" aspects of these polities and may have played an important role in their eventual decentralization as well. Both Bruce Smith and Timothy Pauketat have very persuasively marshalled evidence and arguments challenging the view that centralized chiefly power was founded on control or direction of the internal political economy, specifically the subsistence economy. I agree, and in the same spirit focus my comments on various dimensions of political ideology that were expressed or implied in these papers and that I have been exploring in my own recearch. Yet it is important to emphasize, as both Smith and Pauketat do, that such a position is not intended to imply a total dismissal of material factors in understanding cultural development. It seeks instead to probe more deeply into the political-ideological context within which material factors also operated.

Beliefs and activities constituting political ideology highlight the responsibility of high chiefs or other elites to deal with temporal and spatial distance, meaning that portion of the universe that lies outside the spatial and geo-political boundaries of the home polity and that extends temporally 
beyond the immediate here-and-now of the home center. This politically and ideologically relevant outside domain surrounds the home society in all directions. It not only extends conceptually upward to the heavens and downward to the netherworld but also reaches horizontally outward in every direction to geographically distant locales.

In native ideologies and cosmologies world wide, phenomena located in or otherwise associated with the outside are regarded as specially charged or embued with distinctive energies and qualities. These powers are attributed because temporal/spatial distance, whether vertically or horizontally situated, basically relates to concepts of origins and creations, specifically to earthly creation, human beginnings, cultural origins, and the facilitators of such epiphanies. Such primordial creators, in turn, conform to two basic types: they are regarded either as named and personalized creator deities, ancestors, and culture- heroes or as more anonymous or impersonal primordial powers (Balandier 1970:106 and chap 5 passim; Davenport 1986:103-4).

To the extent that living chiefs and other political elites can become identified with such distant or outside ancestral beings and creational phenomena they, too, become identified with processes of creation and cultural origins. Relating themselves to original and creative ancestral powers, political elites identify and legitimize their statuses, roles, and political prerogatives not only as part of the god-given nature of things but also as associated with inceptions of morally proper, cultured, human social living. By placing themselves in company with the ancestral powers and culturehero creators of ideal human behavior, elites also seek to become related to the qualities of absolute "truth" and control that by definition are associated with concepts of origins. In other words, by evidencing outside ties, political elites try to establish their positions and their proclamations as unassailable, for that which is associated with sacred distance and with origins, that is, with places and conditions far removed from the present and thus incapable of direct or "empirical" examination by persons living in the here-and-now, may not be as readily challenged by political rivals or successfully shown to be false by would-be disbelievers (Howe 1986:83-84; Seeger 1987:49).

Although the hope of attaining unassailable legitimacy and authority may lie at the heart of elite concerns with outside realms, the specific nature of outside phenomena itself, the particulars of contacts with such domains, and the modes of expressing or evidencing such contacts and relationships to the home society are quite diverse. The papers presented in this volume provide a considerable range of representative examples.

Bruce Smith's discussion of solar links as tangibly manifested by the woodhenges at Cahokia directly addresses one of the most fundamental dimensions of indigenous cosmologies (see also Pauketat). I fully concur with Smith when he emphasizes chiefly mediations with this portion of the cosmological realm as crucial to the development and legitimation of Mississippian elite roles and statuses. Ultimately the basic quality sought in the solar or celestial realm relates to the life-giving properties of the sun and rain, which are associated not so much with their physical manifestations per se as with energies or potencies of light and water that originated at creation and still conjoin all living things within an ordered cosmos. It is essential to realize what belief in such a consubstantiality of life (as Goldman terms it) entails if we are to understand how manipulation of this concept empowers political authority. Irving Goldman, speaking of the Kwakiutl, explains succintly:

To say of the Kwakiutl that they were deeply religious is to say no more than what is true of all American Indians and probably of all primitive peoples, for whom religion means involvement in a consubstantial nature. Scientific materialism postulates the consubstantiality of matter, primitive religions that of life and the powers of life. In their ritual setting the Kwakiutl are in daily touch with forms of life and with sources of power to which they should respond if they are prudent and energetic. There are rivers and ponds 
whose waters are the 'water of life,' of which they should drink. They need the good will of all animals upon whom they feed. They ask permission of trees for their planks, of the sun for its general help. They will not hunt or fish without preparing themselves ritually for the encounter. From a materialistic point of view that recognizes only the utility of killing, the ritual of hunting and fishing preparations is for success. From the Indians' point of view, the ritual serves to prepare men to enter the foreign realm of the animals by making them acceptable to the animals. [Goldman 1975:22]

The all-encompassing energies of life are evidenced "empirically" in numerous and diverse natural and human phenomena. They are revealed not only in the ubiquitous growth and fertility of people, plants, and animals but also in more existential phenomena. Among the foremost of these (and returning to Smith's theme of solar associations) are the quality of luminosity and the spread of the color spectrum, both of which are found virtually throughout nature not only in the rainbow proper but also in the display of colors revealed in drops of water, rotated shamanic quartz crystals, and wet clay, on iridescent birds' feathers, the sheen of furred pelts, and reptiles' skins, in colored stones and gems (congealed light) and wet shells, and in the shine or glow deliberately given by human artisans to burnished metal, glazed or painted ceramics, brightly decorated textiles, and polished stone and wood (Reichel- Dolmatoff 1978:262 and 266, 1987:4; Morphy 1989; Eco 1986).

Human acquisition of these and other tangible manifestations of luminosity or color or other qualitative characteristics, such as particular sounds or odors, constitutes acquisition of the qualities or energies encompassed therein (Reichel-Dolmatoff 1963). One of the most familiar expressions of such acquisition is mentioned by both John Scarry and Tim Pauketat, who document the well-known association of high status burials with exotic grave goods. These goods are valued precisely because they relate to portions of the cosmological beyond and are believed to be literally imbued with supernatural potencies and qualities expressive of that realm. For the same reason interment of such goods does much more than document high status or provide materials necessary for a comfortable afterlife. Ownership of such goods in life directly relates the individual acquiring them to the supernatural potencies and qualities such goods are believed to possess and evidences his or her success in contacting or dealing with the distant realms whence such goods originated. In like fashion ceremonial burial of such potent wealth at death literally identifies and creates a functioning ancestor. Burial of wealth becomes a way of empowering the now deceased accumulator with the qualities and energies he or she will require in order to continue to serve the living as a beneficient ancestor. While genealogical connections or particular statuses such as being the first born or the head of household or lineage may formally identify an individual as a potential future ancestor, this role becomes activated or energized after death by funeral rituals that may include (among other things) the accompanying internment of energy-filled valuables (Harms 1981:210).

In a related vein, a crucial key to understanding how political inequality develops within a polity may lie in elucidating the mechanisms that allow successful monopolistic access to and accumulation of such valued prestige goods by influential persons while still alive. Although many studies have emphasized the political use of accumulated goods once in hand, including how they are gainfully distributed, the prior acquisition of such goods carries considerable political weight in and of itself. This is so because, like solar/ calendrical calculations, the accumulation of valued tangible items signals control of time and space. Such accumulation, like calendrically determined ceremonial cycles, also speaks directly to the ability of living lords to acquire and transform the essential life- giving qualities of the wider cosmos so that they may be made available to energize the social life and social reproduction of the polity.

Let us pursue this point a bit further. Tangible luxury or prestige goods exist in two formats. 
They may be crafted items acquired ready-made from geographically distant places or skillfully fashioned at home from materials - woods, clays, stones, metallic ores, paints - that are also derived from the outside world. Alternatively, some prestige goods may be valued in their natural, unworked form as inherently endowed with qualitative worth - animal pelts, shells, feathers, and the like. All these items, both those that are skillfully crafted and those that are naturally endowed, constitute a type of inalienable wealth, meaning they are goods that cannot be conceptually separated from their place or condition of origin but always relate whoever possesses them to that place or condition (Weiner 1985). In the case of elite prestige goods, the inalienable place or condition refers to temporal/ spatial distance and to conditions of origins, particularly to the primordial ancestral beings - creator deities, culture-heroes, primordial powers - that are credited with having first created or crafted the world, its creatures, its peoples, and their cultural skills. Such inalienability can be expressed in various ways. When prestige goods are crafted from natural materials, the raw materials themselves--the clays or ores or woods or stones--are believed to be potent sources of power. "It is the spirit of the tree, the spirit of the fibre, and the spirit of the elephant that go to the making of the composite drums which are honored equally with the names of the dead kings" (Rattray 1927:186). In addition, the artisan's exceptional ability to skillfully craft (create) the finished item is generally believed to be a supernaturally granted and supernaturally guided gift given to an exceptional individual who recreates the original crafting or creational skills of original deities and heroes.

In exactly the same sense goods acquired from distant places - from mountains, the sea, foreign markets, the courts of distant lords - are believed to be literally and inalienably imbued with the extraordinary or cosmological powers of the places and peoples whence they are derived. If they are crafted goods they are also believed to contain the exceptional powers of the distant artists, known or unknown, who fashioned or created them. As Pauketat notes, it is the production and/or acquisition and control of such potent tangible things, which is to say, acquisition and control of the inalienable powers they contain, that lies at the heart of chiefly authority rather than control of things that are merely material or utilitarian, meaning things that lack sacrality and that are quite alienable from their places of production.

In addition, since in traditional societies skilled crafting is regarded as a supernatural gift or ability that recreates the activities of the ancestral creator-craftsmen who originally taught people such skills, and since skilled artisans themselves smiths or potters or painters or sculptors, etc. - are regarded as closely asociated with ancestral artisans, it is entirely appropriate and not at all surprising to find that political leaders are often personally involved with skilled crafting either as skilled artisans themselves or as subsidizers of craftsmen (Tuzin 1978; Rabineau 1975). Here again, Pauketat is quite correct in emphasizing elite production (subsidization) of crafts as well as elite involvement with trade in prestige materials as keys to assessing the development or general condition of chiefly strength. For these reasons I would also be more inclined than Barker to believe the evidence suggesting that the Powhatan chief Wahunsonacock was skilled in ceramics and other crafts.

A different type of production technique can also produce tangible goods replete with politicalideological import. Alex Barker's concern with surplus maize production in Powhatan may be a case in point. Particularly in light of the probable flexibiity in actual collection of chiefly tribute as expressed by the chief's right of first refusal, I would suggest that maize when contained in the Powhatan chiefly storehouses no longer constituted a material resource, like maize kept at home for household consumption, but now became a valueladen tangible resource that (especially in good years when it could be garnered in large quantities) encapsulated another important quality with political-ideological import-the quality of abundance. Stored surpluses of maize (like yams in New Guinea) gave tangible evidence of the well-being of the polity, expressed its health as evidenced in agricultural productivity. Heal th and productivity, in turn, witness that all is well between the population, the leadership, and the outside supernatural powers 
that are believed to be the ultimate source of all human satisfactions.

In like fashion, the efforts by the Powhatan chief, Wahunsonacock, to expand the population of the Powhatan polity particularly at a time when population had significantly decreased may speak at least in part to the same need to tangibly evidence the quality of sufficiency, if not of abundance - in this case sufficiency expressed in number of people, the "bottom line" indicator of successful politics in traditional societies in general. In the eyes of both Powhatan chiefs and the population in their care abundant people and abundant maize stores may have related not only to earthly economic tribute but also to evidence of chiefly success in mediating with and controlling the powers of the universe without whose beneficent assistance neither people nor produce could be successfully reproduced and "grown". The large (abundant) number of wives technically belonging to the high chief and their chiefly distribution as wives to the men of the polity fits this paradigm very nicely, too. It again highlights the chief as a provider of abundance in the context of human life as evidenced now in social reproduction by means of female fertility. Such acts would have allowed high chiefs both to emulate (or at the very least be seen as assisting) the beneficent outside powers and ancestors that provide life in general and to be recognized as beneficent "creators" in their own right.

Perhaps what may appear to be a degree of chiefly populism as expressed by the Powhatan chief's simple, commoner-like clothing is also relevant here. Although such behaviormay indicate a chief who is sinking beneath political weakness it may also be taken to signify one who is regarded as having risen above or stepped beyond the routine status distinctions and social contrasts of society per se, contrasts structurally represented by distinctions in costume between commoners and lesser ("ordinary") elites. As Barker notes, by such means the ruler surmounts the particulars of status differentiation to become identified with the wider realm as a whole. Such a chief may counter the differentiating hierarchical levels of the polity with the unifying ideal of a shared humanity held in common by everyone; a humanity that relates commoners to their chief as the ideological heart of the polity through whom everyone could be still further related to the universal whole within which human society was encapsulated.

However it was done, probably by attention to both ecological and ideological principles, a reasonably healthy population seems to have lived in the Southeast chiefdoms, certainly in the case of Moundville, as Mary Powell has documented. Her discussion also introduces the topics of warfare and of hunting. Both of these need to be carefully considered not only in conjunction with physical well-being but also as activities with ideological as much as ecological significance, for in traditional societies both activities are typically conducted in locales geographically and cosmologically beyond (outside) the settled, inhabited areas of the polity taking the initiative in such affairs.

Judging from ethnographically based inferences (Peebles and Kus 1977:425; Goldman $1975: 3,22,43,52-53)$, hunting in untamed or uncultivated - meaning uncultured - forests or bush beyond the bounds of settled society can be considered a particularly honorable elite activity. It is comparable to long-distance trade and to skilled crafting in that it is a strongly ritualized activity involving acquisitional and transformative dealings with outside powers (e.g., supernatural masters of animals) and since success in hunting frequently is taken as evidence of supernatural approval and support. It is for such reasons that hunting, like various skilled arts and crafts, has long constituted a favorite elite "pasttime" and royal "sport". Similarly, the political significance of warfare rests at least in part on the identifications accorded the enemy, who are often considered to represent the forces of the non-moral or evil or uncultured portion of the universe arrayed against the truly human characteristics of the socially and morally "good guys". Whatever else it may achieve, in many traditional societies warfare frequently takes on characteristics of a morality play, one that, like hunting, is generally conducted under elite guidance and auspices in centralized polities.

Another very important way of tangibly evidencing the legitimacy of leadership and politi- 
cal centricity is seen in the construction, meaning the skilled building, of public edifaces as part of the cultural landscape. Not surprisingly, as one of the ultimate expressions of skilled crafting this activity is also one of the most significant and popular of tribal, chiefly or kingly enterprises. Included here are the raising of modest lineage or community houses whose construction identifies a lineage or tribal leader (Goldman 1963:155 and 1940:348349) as well as the building of extensive royal compounds, temples, or primate cities which could allow a royal lord to claim "now I know that I am indeed a king, for I have built myself a city and live in it" (Hillenbrand 1988:26). Included here, too, are the public plaza complexes, earthworks, and mounds of the chiefdoms of the Southeast, constructions that literally represented the political centers of earthly polities and literally rose as axes mundi towards the solar/celestial dimension of the beyond; constructions like the mounds at Cahokia that Tim Pauketat discusses, the earthworks at Toltec considered by Michael Nassaney, who notes the careful, skillfull planning and conceptualization of design evidenced by the site, and the burial mounds of the Coles Creek culture described by Kidder where, singly or in kin groups, deceased elites conjoined the still living with their ancestral origins (see also Frankfort 19148:269-274).

Pauketat's paper also draws our attention to the diversity of activities devoted to political ideology in an ongoing polity. He recognizes the usefulness and significance of iconographically decorated ceramics (an important skilled craft) as a canvas for tangible depiction of cosmological concepts. He stresses the importance of chiefly acquisition of outside-related exotic artifacts. He notes the multivocal symbolism of monuments and buildings associated with elites and insightfully comments on the bit-by-bit incremental construction of structures and mound terraces. This ongoing repeated process of building might be construed not only as periodic rites of intensification or of world renewal but also as continually evidencing the significance of the concept or the act of skilled crafting. Such building, as a type of key symbol, would literally epitomize the belief that chiefs were fundamentally master builders, meaning ancestor-like creators constantly concerned with cultural order and societal well-being.

Pauketat further considers the significance of possible changes in the magnitude of some of these diverse expressions of lordly sanctification and legitimation. This subject is particularly intriguing, for it suggests that differential political weightings may be attributed to chiefly association with the celestial or vertical axis of the cosmos compared to involvements with the geographical or horizontal beyond. In like fashion, Kidder weighs material evidence for the presence or absence of both "indigenous" activities (which presumably would include religious or vertical associations) and geographically external activities that would relate to the social and political evolution of Coles Creek culture. Both Kidder and Pauketat are particularly concerned with understanding both the development and/or sustaining of political centralization and the eventual decentralization of such polities. Obviously, too, similarconsiderations also precede and precondition chiefdom development. Various activities directed toward both the vertical and the horizontal axes of the cosmos are not only reserved for elites of emerging or already centralized polities but are evidenced in the activities of influential individuals of non- centralized societies, too.

Referring to Fort Ancient societies, for example, Griffin notes that metal, shell and ceramic artifacts - crafted or outside-derived trade items all of which were probably thought to be imbued with sacrality - were interred with the remains of many individuals. Similarly, ethnography from-many geographical areas attests to the widespread belief in so-called egalitarian societies that the entire population as well as the leadership must work equally to support cosmic proprieties by careful attention to social proprieties. Here, too, these essential goals are expressed by (among other things) diverse types of skilled crafting, acquisition of ideologically potent tangible goods from afar, hunting, and warfare. In less centralized "tribal" societies, however, these activities frequently are considend the prerogative of every initiated adult (Goodale and Koss 1967:187-188; Messenger 1973:125-126). In contrast, the particular 
potency of chiefly power in chiefdoms (and states) resides in the manner in which such enterprises are now disproportionately channeled to and focused upon the activities of a limited number of political elites, who become subsidizers, specialists, or even monopolists in such affairs (see Scarry, this volume). For those interested in understanding how political centralization and hierarchy may have evolved historically, one of the avenues of inquiry involves understanding just how such restricted access is achieved (Allen 1984; Nassaney, this volume). This line of thought may also help explain the rationale by which those who do achieve restricted access are accorded an inherent quality of exceptional personal honor and pedigree, that is, of eliteness, believed to surpass that of ordinary folk (Goldman 1970: chaps. 1 and 20).

At the other end of the processual sprectrum, understanding the apparent demise and decentralization of polities such as Cahokia (Pauketat) or the abandonment of mound centers as at Lake Jackson (Scarry) is as difficult as understanding the processes that brought them into existence. Demise, of course, really means reorganization, either at a lesser or at a greater degree of political complexity (Nassaney, this volume). Realizing that the full extent of political associations, particularly on a wider regional level, may be difficult to document, nonetheless reduction or decentralization in external linkages seems to correlate with significant change in political emphases at Cahokia and perhaps with Lake Jackson, too.

Even if active political life seems to shift, decentralize, or localize, former elite centers may continue to function as places of power, that is, as places where ancestral connections can still be made. Just as contemporary Lacandon Indians continue to make offerings at ruined Mayan pyramids because they are power-filled sites where the dead can be contacted (McGee 1990:52, 57), so seemingly abandoned elite centers in the prehistoric Southeast may have continued to function as "centers- out-there" (Turner 1972). Such centers frequently serve as regional places of pilgrimage. As burial sites they may be further identified with crucial points on the cosmographical horizon where direct contact may be believed to occur between the earth and the heavens (or the underworld) allowing the passage of ancestral souls between cosmological domains.

Speaking of linkages with distant domains, Marvin Smith and David Hally's analysis of the receptions accorded to Spaniards by local chiefs provides additional details of some of the ways elites dealt with tangible representations of the world beyond. It is hard not to be impressed by the sang froid with which lords of the Southeast and elsewhere initially met the Spaniards. It is as if they were mentally and emotionally familiar and at home with the experience, even though in many ways the newcomers must have appeared very strange to them. Indeed, evidence suggests that the Spaniards were perceived as tangible forms or guises or tutelaries of long familiar outside beings deriving from cosmologically distant settings. The suggestion that the receiving chiefs initially regarded the Spaniards as lords embarked on periodic pilgrimages through their realms is compelling. It is reminiscent not only of the Hawaiian progress of paramount chiefs representing the god Lono which, as Smith and Hally correctly note, has parallels in the royal progresses of many other types of royal rulers (Geertz 1977) but also of the resulting Hawaiian identification of Captain Cook as tutelary of Lono embarked on his annual tour as god (Sahlins 1981:10-11,18-25).

Finally, I would reiterate that greater sophistication in comprehending the complex dynamics of political activities, including processes of centralization, may require realization that contacts between political leadership and the various dimensions of outside worlds may be qualitatively interchangeable. In other words, contacts between a home polity's chiefs and celestially or chthonically located deities, ancestors, and culture heroes may be ideationally and politically complementary or equivalent to contacts between those same chiefs and representatives of select places or polities that are geographically distant. Success or failure in dealing with either or both outside domains can directly relate to success or failure in political affairs at home. Similarly, patterns of political life may differ according to which axis of outside sacrality is emphasized and under what conditions. 
In short, the most significant key to understanding the development and operation of the highest levels of political dynamics in traditional societies, including chiefdoms, may lie less in managerial directives within the here-and-now of societal life at home and more in the manner in which all types of foreign affairs involving all expressions of temporal/spatial distance are conducted for both societal and elite benefit.

\section{REFERENCES}

Allen, Michael

1984 Elders, Chiefs and Big Men: Authority Legitimation and Political Evolution in Melanesia. American Ethnologist 11:20-41.

Balandier, Georges

1970 Political Anthropology. New York: Pantheon Books, Random House.

Davenport, William $\mathrm{H}$.

1986 Two Kinds of Value in the Eastern Solomon Islands. In The Social Life of Things, edited by Arjun Appadurai, pp. 95-109. Cambridge: Cambridge University Press.

\section{Eco, Umberto}

1986 Art and Beauty in the Middle Ages. New Haven: Yale University Press.

Frankfort, Henri

1948 Kingship and the Gods. Chicago: University of Chicago Press.

Geertz, Clifford

1977 Centers, Kings, and Charisma: Reflections on the Symbolics of Power. In Culture and Its Creators, edited by Joseph Ben-David and Terry Nichols Clark, pp. 150-171. Chicago: University of Chicago Press.

Goldman, Irving

1940 The Alkatcho Carrier of British Columbia. In Acculturation in Seven American Indian Tribes, edited by Ralph Linton, pp. 333-389. New York: D. Appleton-Century Co.

1963 The Cubeo: Indians of the Northwest Amazon. Urbana: University of Illinois Press.

1970 Ancient Polynesian Society. Chicago: University of Chicago Press.

1975 The Mouth of Heaven. New York: John Wiley \& Sons.

Goodale, Jane C., and Joan D. Koss

1967 The Cultural Context of Creativity Among Tiwi. In Essays on The Verbal and Visual Arts, 
edited by June Helm, pp. 175-191. Proceedings of the 1966 Annual Spring Meeting of the American Ethnological Society. Seattle: University of Washington Press.

Harms, Robert W.

1981 River of Wealth, River of Sorrow. New Haven: Yale University Press.

Hillenbrand, Robert

1988 The Symbolism of the Royal Nimbus in Early Islamic Art. In Kingship, edited by Emily Lyle, pp. 1-52. Cosmos, vol. 2. Edinburgh: The Traditional Cosmology Society.

Howe, James

1986 The Kuna Gathering: Contemporary Village Politics in Panama. Austin: University of Texas Press.

McGee, R. Jon

1990 Life, Ritual, and Religion Among the Lacandon Maya. Belmont, CA: Wadsworth Pub. Co.

Messenger, John C.

1973 The Role of the Carver in Anang Society. In The Traditional Artist in African Societies, edited by Warren d'Azevedo, pp. 101-127. Bloomington: Indiana University Press.

Morphy, $\mathrm{H}$.

1989 From Dull to Brilliant: The Aesthetics of Spiritual Power among the Yolngu. Man 24:2140.

Peebles, Christopher and Susan M. Kus

1977 Some Archaeological Correlates of Ranked Societies. American Antiquity 42:421-447.

Rabineau, Phyllis

1975 Artists and Leaders: The Social Context of Creativity in a Tropical Forest Culture. In The Cashinahua of Eastern Peru, edited by Jane Dwyer, pp. 87-109. Haffenreffer Museum of Anthropology, Studies in Anthropology and Material Culture, Vol. l. Brown University.

Rattray, R. S.

1927 Religion and Art in Ashanti. Oxford: The Clarendon Press.

Reichel-Dolmatoff, Gerardo

1963 Things of Beauty Replete with Meaning - Metals and Crystals in Colombian Indian Cosmology. In Sweat of the Sun, Tears of the Moon, edited by Peter Furst, pp. 17-33. Los Angeles: Terra Magazine Pub. and Natural History Museum.

1978 Desana Animal Categories, Food Restrictions, and the Concept of Color Energies. Journal of Latin American Lore 4:243- 291.

1987 Shamanism and Art of the Eastern Tukanoan Indians. Institute of Religious Iconography, 
State University Groningen, Iconography of Religions, Section IX: South America; Fascicle 1. Leiden: E. J. Brill.

Sahlins, Marshall

1981 Historical Metaphors and Mythical Realities. Ann Arbor: The University of Michigan Press.

Seeger, Anthony

1987 Why Suyá Sing. Cambridge: Cambridge University Press.

Turner, Victor

1972 The Center Out There: Pilgrim's Goal. History of Religions 12:191-230.

Tuzin, Donald F.

1978 Politics, Power, and Divine Artistry in Ilahita. Anthropological Quarterly 51:61-67.

Weiner, Annette B.

1985 Inalienable Wealth. American Ethnologist 12: 210-227. 